\title{
The development of venture capital in Latin America and the Caribbean: a comparative perspective
}

\author{
Ernesto H. Stein and Rodrigo A. Wagner ${ }^{1}$
}

\begin{abstract}
Venture capital (VC) contributes to the financing of high-growth companies. In Latin America and the Caribbean, this capital is lower than in China and India as well as the developed economies. Nonetheless, between 2005 and 2011, regional VC investments grew by $30 \%$ per year. Venture capital investments in Latin America and the Caribbean tend to be larger, focus less on high-technology industries and are more likely to be funded from abroad than those in benchmark regions. Transactions in Latin America and the Caribbean are made by less experienced investors and in fewer rounds than in comparator countries. Venture capital growth has been quite procyclical. The evidence shows that VC investments are in the early stages of development, with apparently more money than high-technology ideas.
\end{abstract}

\section{Keywords}

Venture capital, investments, enterprise development, comparative analysis, statistical data, Latin America

\section{JEL classification}

G24, L26

\section{Authors}

Ernesto Stein is Principal Economist with the Research Department of the Inter-American Development Bank. Email: ernestos@iadb.org.

Rodrigo Wagner is an Assistant Professor with the School of Business of Universidad Adolfo Ibáñez (UAl), Chile. Email: rodrigo_wagner@post.harvard.edu.

The authors gratefully acknowledge the support provided to this research by an anonymous referee, Susana García-Robles and her team at the Multilateral Investment Fund (MIF), and Juan Savino from the Latin American Venture Capital Association (LAVCA). The authors also acknowledge useful comments received at the Conference on Model-based Evidence on Innovation and Development (MEIDE) and from the Inter-American Development Bank (IDB). This research was partially funded by a grant from the IDB Research Department project, Understanding Venture Capital in Latin America. 


\section{Introduction}

According to Rajan (2012), the fundamental tension in corporate finance is caused by the interplay of two forces. Firstly, an entrepreneur has to produce innovative and differentiated assets that create new value, otherwise the enterprise would be unlikely to take market share. Secondly, the entrepreneur has to be able to credibly promise a fraction of the value created by these new assets to an outside investor, in order to obtain external finance. The problem arises because the more differentiated and the less known the asset, the harder it is to credibly pledge income from the project to a third party who finances it but does not control it. This creates constraints for new types of technology, because projects that are potentially profitable may not receive funding because of this credibility problem (also known as pledgeability concerns).

Fortunately, this major constraint on new, innovative businesses can be mitigated by using a form of financing that departs from arm's length transactions, adopting instead an active monitoring role and conditional control rights, which improves the pledgeability of the project and thus its chances of obtaining funding. The type of financing in question is venture capital (VC), which has enjoyed spectacular growth in recent decades, and has been especially important for the financing of highly innovative start-ups in the United States.

Venture capital has also been taking off in Latin America, albeit on a much smaller scale. Nonetheless, while a few studies have touched on specific features of this process, there is currently no academic work examining the basic stylized facts of recent VC development in the region. This is an inconvenient gap because Latin American governments are increasingly looking to foster the entrepreneurial ecosystem; and international development institutions are actively participating as partners in this process. For example, the International Finance Corporation (IFC), part of the World Bank Group, and the Multilateral Investment Fund (MIF), which is the investment arm of the Inter-American Development Bank (IDB), have acted as limited partners in private equity financing in the region, with a significant focus on $\mathrm{VC} .^{2}$

This article provides a quantitative overview of VC investments in Latin American firms. Wherever possible, it provides a comparative perspective showing how the various characteristics of Latin American VC investments differ from those in other regions of the world.

It is worth starting this process by noting the main limitations of the exercise, the most important of which stems from imperfect data availability, since VC investments do not target publicly traded corporations. Nonetheless, VC financing could play a pivotal role in the development of the private sector in Latin America, so it is worth exploring the patterns that emerge from the available data, even if they are imperfect. ${ }^{3} \mathrm{~A}$ second limitation arises from the exploratory nature of this study, which aims to provide an overview of $\mathrm{VC}$ in the region. The study will make gross simplifications that mean ignoring many country-level specifics that are potentially relevant. Lastly, a third limitation stems from the previous two. It is tempting to read comparative data across countries as if they were rankings of national soccer teams, where even small differences between neighbouring countries can become sources of national pride or shame. However, readers should resist this temptation in this instance because data for the region are incomplete and volatile, so it is difficult to identify statistical noise and second-order differences.

\footnotetext{
2 Venture capital is a subset of private equity. Between 1996 and 2010, MIF invested a total of US\$215 million in private equity in the region. More than $30 \%$ of recorded private equity investments were made at the beginning of that period. Since then, other players have entered the market, so the share of these types of institutions is decreasing.

3 Venture capital is a minuscule fraction of overall macroeconomic investment, even in the United States, but particularly in Latin America. Countries value it for its potential to unveil new business models, rather than for its mechanical effects through aggregate investment. Macroeconomic investment is equivalent to $23 \%$ of gross domestic product (GDP) (see table A1.1 in the annex). The unweighted global average VC-to-GDP ratio across countries is $0.04 \%$. In Latin American countries, VC investments are in the neighbourhood of $0.01 \%$ to $0.04 \%$ of GDP; and in the United States they are equivalent to $0.18 \%$ of GDP.
} 
As noted above, the aim of this study is to add to the sparse literature that exists on VC financing in Latin America, focusing more on broad quantitative patterns than on either the relevant qualitative aspects or a single economic mechanism. While there is limited literature on the topic, this study is not the first to examine VC in Latin America. For example, Bruton, Ahlstrom and Puky (2009) use expert interviews and qualitative analysis to compare VC practices in Asian and Latin American countries. The present study takes a more quantitative approach, examining the amounts and types of investment. In that regard, it is closer to Khoury, Junkunc and Mingo (2012), who drew on data from Thomson Reuters for the period 1995-2004 on VC investments in Latin America. Those authors show that the average size of investment per round in the region tends to be larger in countries that have weaker institutions. They argue that when venture capitalists face institutional uncertainty they tend to avoid early-stage investments, which require more intensive staging and multiple investment rounds, preferring projects that are at a later stage of development. ${ }^{4}$ The approach taken by this paper differs not only in terms of the time horizon -extended to 2011- but also because it explicitly compares VC investments in Latin America with those in other regions of the world, to identify what is different and distinctive in Latin America. This study seeks to reveal broad patterns, rather than focusing on a single mechanism. Along similar lines, Jiménez (2008) was also interested in VC patterns and policy, but his analysis only encompasses aggregate data for Brazil and Chile. This paper uses two sources or microdata, namely the new Latin American Venture Capital Association (LAVCA) database, with data covering the period from 2008 to 2011 and Thomson ONE, with data from 2000 to 2012. Wherever possible, two data sources are used explore whether a particular stylized fact is robust to data-collection differences. ${ }^{5}$ Overall, this study complements the recent review of alternative investments in emerging markets made in Cumming and Zhang (2016), by comparing Latin America with other regions.

The main findings of the study are that, in keeping with other sources, it confirms that $\mathrm{VC}$ financing in Latin America is clearly orders of magnitude below that of developed economies; but more importantly, the VC-to-GDP ratio in the region is also well below those of the regions that are home to China and India, despite the lower per-capita income levels of those regions.

Nonetheless, despite starting from a low base, since 2005, VC investments in Latin American companies have been growing by an average of more than 30\% per year, with around one quarter of all such deals being made by foreign VC investors.

The study establishes a number of stylized facts about VC investments in the region. Firstly, VC investments in Latin America tend to be in less high-technology ventures than in other regions of similar income level. Secondly, the average project size is larger than in these comparator regions, although the size difference is mostly explained by the fact that non-high-technology projects are larger. Thirdly, venture capitalists from outside the region invest significantly larger amounts in Latin American firms than those from the region. Fourthly, VC firms that invest in Latin America have significantly less experience than those investing in other world regions, with the sole exception of Sub-Saharan Africa. Fifthly, VC investments are heavily dependent on the business cycle in the host country. This procyclicality is three times stronger for $\mathrm{VC}$ than for macroeconomic investment in the region, and six times stronger than the procyclicality displayed by VC outside of Latin America. Taking these facts together, the evidence points to an underdeveloped VC ecosystem that is in its early stages.

\footnotetext{
4 Liao, Lu and Wang (2014) examine the success of VC-backed firms in emerging markets when taken public through an initial public offering (IPO). Otchere and Vong (2016) explore the effects of VC-backed firms on the pricing of IPOs in China.

5 Pereiro (2001) surveyed various sources of entrepreneurial finance in Argentina compared to out-of-sample estimates from developed countries, concluding that "(a) it takes on average more money for the Argentinian entrepreneur to start a de novo venture than for his/her counterparts in the United States; (b) operational parameters of formal private equity or VC funds are in line with international standards; and (c) Argentinian angels invest on average substantially higher amounts per venture than their counterparts in other countries, being also younger than the international average." Unlike that study, this one relies on comparable data from various Latin American countries and, in some cases, uses data from the same databases in the region.
} 
Lastly, the study explores which variables explain the differences in levels of VC development among countries, measured as the VC-to-GDP ratio. The results show that the factors driving the demand for VC, such as patents and scientific articles, explain a significant part of the VC-to-GDP ratio. The size of the market is also important. In contrast, the study did not find a significant link between VC development and the factors associated with the supply of funding, measured by stock market capitalization as a percentage of GDP. Large countries with high levels of patenting activity tend to have more developed VC markets. This is relevant for discussions on Latin American innovation and integration.

\section{Sources of data on venture capital investments in Latin America}

Historically, VC data collection is still in its infancy in less developed economies, as was the case with GDP measures was in the early 1900s, or as empirical studies of corporate finance of publicly traded companies used to be before standardized data were available. Unlike data on GDP and public enterprises, the availability and reliability of $\mathrm{VC}$ data is unlikely to improve very fast since the vast majority of transactions take place between private parties that have no legal obligation to report to a centralized clearing house. There is therefore no point in waiting to explore the available data. It would also be a mistake to take every single aggregate figure at face value, partly because data collection is still in its infancy, but also because classification criteria are not yet standardized across reporting sources. For example, an injection of US\$500,000 into a website in Colombia that claims to be the new e-Bay is probably an early-stage $\mathrm{VC}$ investment, but what about a relatively new family firm with a successful business model that wishes to expand? This would normally be classified as non-VC private equity; but it could be an example of VC financing, depending on the circumstances. One criterion is the age of the firm, another is the type of contract used and the novelty of the technology, as well as the size of the investment. Since many figures are self-reported, the organizations that collect the data also consider the orientation of the reporting fund. The annex to this article discusses the criteria in question, noting that databases may have different classifications, but those differences are hard to pin down.

In short, this article will describe broad trends and will identify the differences between and potential biases of the two data sources.

\section{Comparing the two sources: similarities and differences}

The two main data sources are, firstly the updated dataset produced by LAVCA, covering the period 2008-2011; and, secondly, transaction-level information from the Thomson ONE Private Equity Module (formerly VentureXpert). The sample is drawn from the period 2000-2012, but emphasis is placed on the trends displayed in 2005-2012. The annex provides details on both samples. ${ }^{6}$

It is important to clarify that the two databases obtain their information from different reporting sources and might not be measuring exactly the same phenomenon. ${ }^{7}$ Thomson ONE information is sourced through direct submissions by global private equity and VC firms, and banking and legal contributors. Although it is not explicitly stated, the manner in which the data are reported would tend to give undue weight to large investments and those involving foreign firms. In contrast, LAVCA data

\footnotetext{
6 Although data since 2000 are certainly available, the authors of this study preferred to examine new trends and limit the scope to a period where data, albeit imperfect, have a higher deal density, otherwise the figures would become too volatile to be able to draw any conclusions.

7 Another leading source for VC research, Dow Jones VentureSource, does not cover transactions in Latin America.
} 
comes from surveying VC firms in Latin America under a confidentiality agreement. This makes the LAVCA data a better resource when considering smaller domestic investors or investors that syndicate less with foreign VC firms, as well as for firms that prefer confidentiality clauses when reporting their transactions. One big advantage of Thomson ONE is that it is possible to observe many more covariates, such as the age of the firms, type of technology, country of origin of the firm and the track record of previous investments for a particular the country in which the VC firm is located. LAVCA data indicate the technology involved and transaction value, but only for the most recent years in the sample. Most importantly, Thomson ONE data allow Latin America and the Caribbean to be compared with other regions. In general, in this study, LAVCA data will be used only to supplement more complex analysis. Nonetheless, it is reassuring to note that the aggregate figures display a high correlation between the two datasets. Using overlapping country-year combinations from the two sources, figure 1 displays the logarithm of the sum of VC investment for Thomson ONE (horizontal scale) and for LAVCA (vertical scale). While there are differences, the results are reasonably close to the 45-degree line.

Figure 1

Latin America (10 countries): ${ }^{a}$ venture capital investments, 2008-2011 (Sum of investments (log scale))

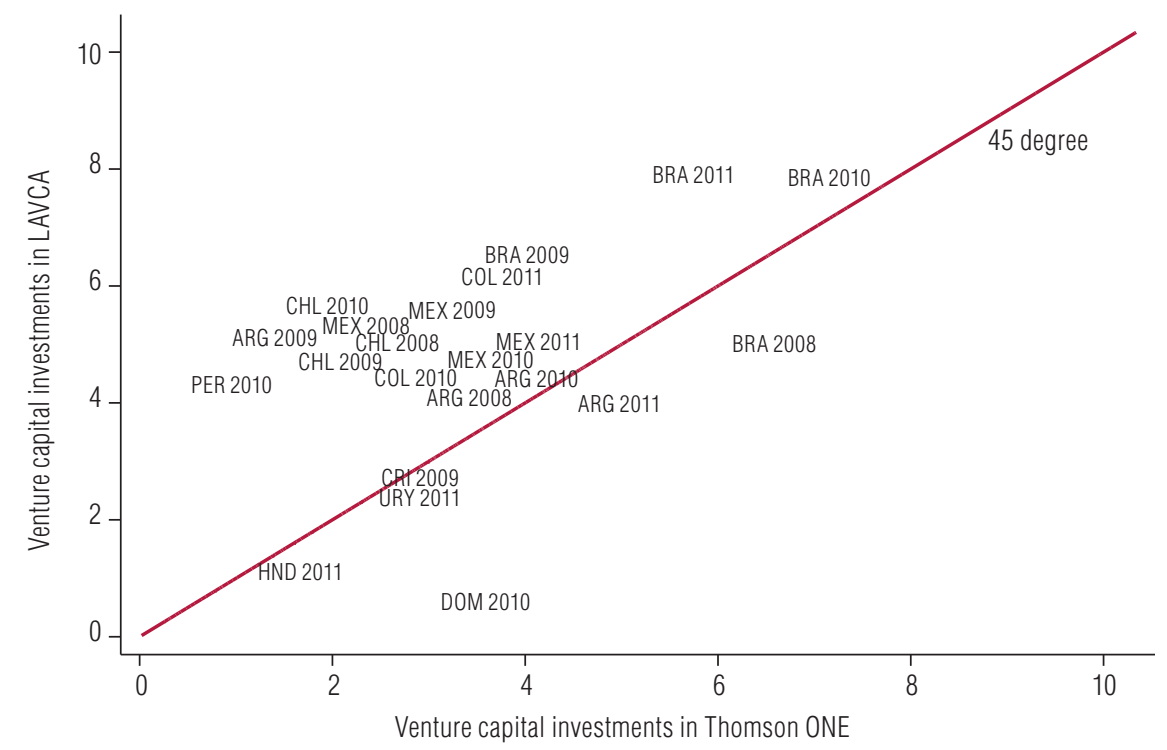

Source: Prepared by the authors, on the basis of data from Latin America Private Equity and Venture Capital Association (LAVCA) and Thomson ONE.

Note: Best fit log of investment in LAVCA $=3.25+0.48^{*} \log$ of investment in Thomson ONE.

a Argentina, Brazil, Chile, Colombia, Costa Rica, Dominican Republic, Honduras, Mexico, Peru and Uruguay.

\section{Venture capital in Latin America and the Caribbean}

This section reviews VC levels and growth in Latin America and the Caribbean from a comparative standpoint. Figure 2 shows how VC investments in the region have evolved since 2000, and it compares this with other regions of the world, based on Thomson ONE data. As expected, the leader in terms of funding is clearly the United States - almost two orders of magnitude ahead of Latin America and the Caribbean - followed by other high-income economies. 
Figure 2

World: total venture capital investments, 2000-October 2011

(Millions of dollars)

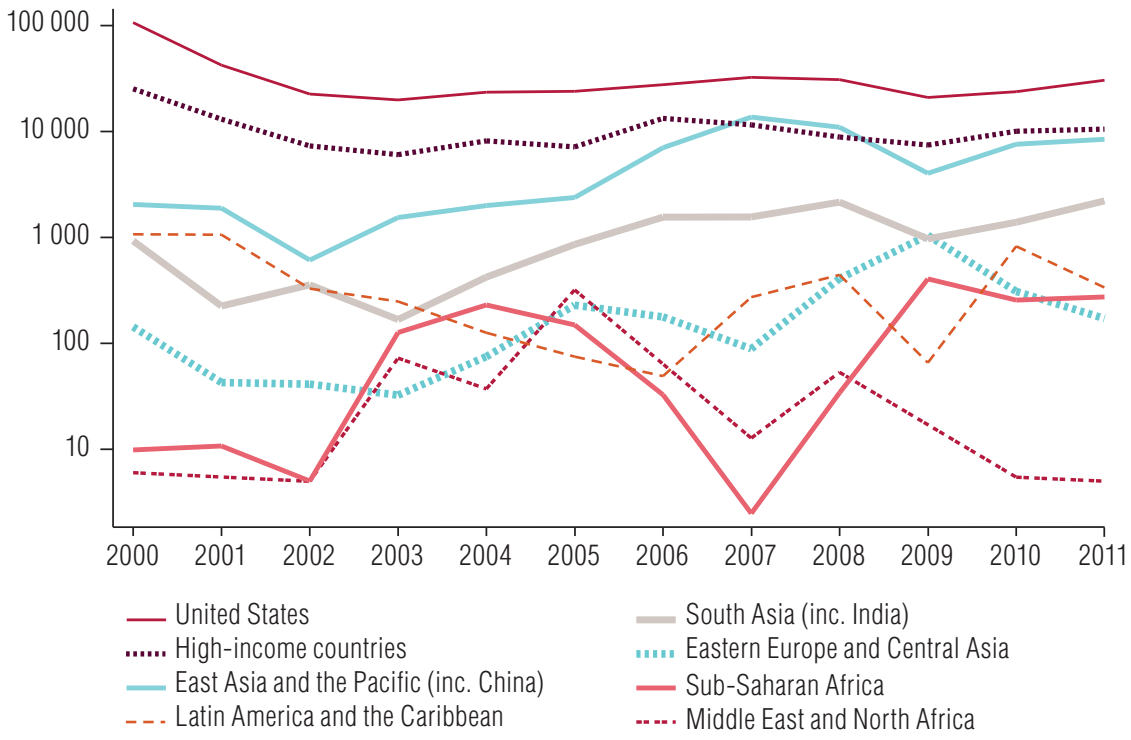

Source: Prepared by the authors, on the basis of data from Thomson ONE.

The region of Latin America and the Caribbean is still currently close to regaining the volumes recorded at the time of the dotcom crash in 2000 , with a trend that resembled an inverted- $U$ with a trough around 2005.

Figure 2 clearly shows that VC flows to firms in the region are relatively more volatile, which is partly explained by the fact that a few large transactions in a given year can drastically change investment totals even though VC development is at relatively low levels. The figure also shows that investment is less volatile in those regions where venture capitalism is more developed, as, proportionally, more transactions take place in those regions, which makes the measurement more stable.

Overall, each year in the period 2000-2011, Latin America received between US\$100 million and US\$1 billion in VC financing, with VC investments growing particularly fast since 2005.

Table 1 displays the trend VC growth rates in various regions between 2005 and 2011 (calculated using log-linear regression). The most salient aspect of the data for the purposes of this study is that Latin America and Caribbean is clearly among the regions where VC investments are growing fastest, together with Sub-Saharan Africa. In Latin America and the Caribbean, the value of VC investments grew at a rate of $31.2 \%$ per year, which is well above the $9.7 \%$ of East Asia and the Pacific (including China) and the $7.6 \%$ per annum of South Asia, including India. During this period, developed regions were essentially flat, as measured by the log-linear trend ( $0.5 \%$ annual growth in industrialized countries excluding the United States, and a $0.1 \%$ decrease in that country).

Additional analysis suggest this rapid growth in Latin America could be a real phenomenon rather than an artefact of measurement, as even though the databases use different recording systems, this rapid growth in Latin America and the Caribbean is qualitatively mirrored by LAVCA data on VC transactions between 2008 and 2011, which showed 53\% annualized growth (part of the difference can be explained by the fact that the starting point for the data is 2008, not 2005). 
Table 1

World: annual growth rates of venture capital, 2005-2011

(Percentages)

\begin{tabular}{|c|c|c|c|c|}
\hline \multirow[t]{2}{*}{ Region } & Volume reported & $\begin{array}{c}\text { Overall No. of } \\
\text { financing rounds }\end{array}$ & $\begin{array}{l}\text { No. of rounds reporting } \\
\text { value invested }\end{array}$ & Reporting rate \\
\hline & (A) & (B) & $(\mathrm{C})$ & $(D)=(C)-(B)$ \\
\hline Sub-Saharan Africa & 39.40 & -3.80 & -3.20 & 0.60 \\
\hline Latin America and the Caribbean & 31.20 & 11.70 & 8.40 & -3.30 \\
\hline East Asia and the Pacific & 9.70 & 14.20 & 8.80 & -5.50 \\
\hline Eastern Europe and Central Asia & 9.70 & -2.20 & -1.20 & 1.00 \\
\hline South Asia & 7.60 & 15.50 & 13.00 & -2.50 \\
\hline High-income countries ${ }^{a}$ & 0.40 & -7.90 & -6.30 & 1.70 \\
\hline United States & -0.10 & 0.40 & -0.60 & -1.00 \\
\hline Middle East and North Africa & -64.70 & -0.50 & -26.00 & -25.50 \\
\hline $\begin{array}{l}\text { Alternative data for Latin America } \\
\text { and the Caribbean }\end{array}$ & 53.50 & 22.40 & 17.60 & -4.80 \\
\hline
\end{tabular}

Source: Prepared by the authors, on the basis of data from Latin America Private Equity and Venture Capital Association (LAVCA) and Thomson ONE.

a Excluding the United States of America.

b Data taken from Latin America Private Equity and Venture Capital Association (LAVCA) covers the period 2008-2011.

A potential concern is that the rate of reporting is changing over time; and the remarkable growth in the region in recent years is a spurious result. But this seems less of a concern because table 1 shows that the rate of reporting has actually dropped slightly in the region, by $3 \%$ per year. This suggests that the growth in VC investment volumes is occurring despite less, rather than because of increased reporting. The LAVCA data reveals a similar situation in the final row of the table. Lastly, the number of financing rounds reported in the region increased by $11.7 \%$ per year according to Thomson ONE data, placing it in the top three regions. In the case of LAVCA data, the number of deals increased by $22 \%$ per year. In short, the two databases present the same qualitative picture of rapid growth in VC investments in Latin America and the Caribbean in the last few years. However, as noted above part of this large growth reflects the very low starting level.

To explain potential changes in the composition of these VC investments in Latin America and the Caribbean, figure 3 describes the evolution of certain characteristics of transactions in the regional portfolio reported by Thomson ONE. ${ }^{8}$ The transactions are disaggregated by syndicated investments, those which involve more than one VC firm; investments in high-technology industries; and domestic private equity investors. It should be borne in mind that transactions may combine different characteristics.

The picture does not suggest a major compositional change during the years of rapid VC investment growth in Latin America and the Caribbean, although the share of high-technology transactions declined following the commodity price boom in 2004-2005. Investments in high-technology firms accounted for around $60 \%$ of total VC financing before that boom and later dropped to a mean fluctuating around $40 \%$. Apart from that, however, figure 3 shows no other obvious trends. The share of syndicated transactions was in the neighbourhood of $10 \%$ to $20 \%$ over the period, while the domestic private equity accounted for between $50 \%$ and $70 \%$ of transactions. ${ }^{9}$

\footnotetext{
8 Shares are weighted by investment round, not by value.

9 One caveat is that Thomson ONE may overrepresent the share of foreign transactions, particularly those originating from the United States or some other large and well-reported economy.
} 
Figure 3

Latin America and the Caribbean: venture capital transactions by specific characteristics, 2000-2011

(Share of total venture capital investments)

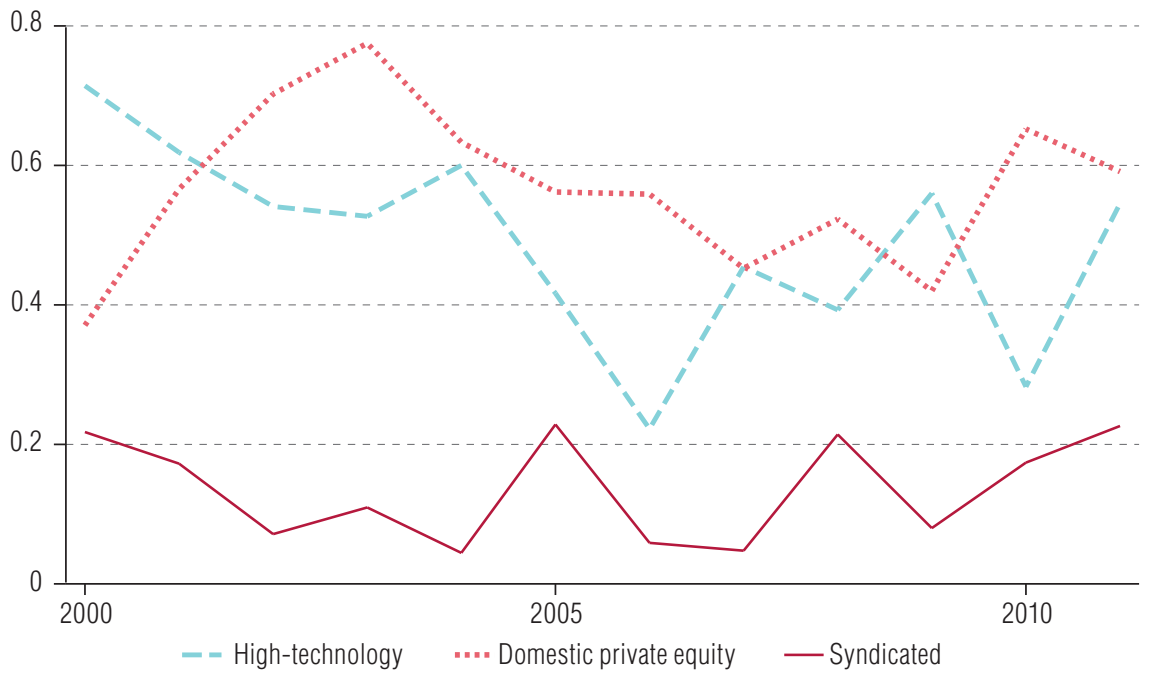

Source: Prepared by the authors.

In order to compare venture capitalism in Latin America with the rest of the world, figure 4 explores the development of $\mathrm{VC}$ financing in different countries by calculating VC investments in each country as a percentage of domestic GDP and then plotting that figure against national per capita GDP, measured in purchasing power parity (PPP) terms. This makes it possible to compare some Latin American economies to other countries, controlling for their level of development and also the size of their economy. The vertical axes of the graphs are measured both in percentage terms and as a log scale, because otherwise it would be impossible to distinguish anything given the very large differences, even when presented as percentages of GDP.

\section{Figure 4}

World (selected countries): venture capital relative to domestic GDP, by per capita income on the basis of purchasing power parity dollars

(Percentages and $\log$ scale)

A. Using data from regional venture capital associations, 2010-2011

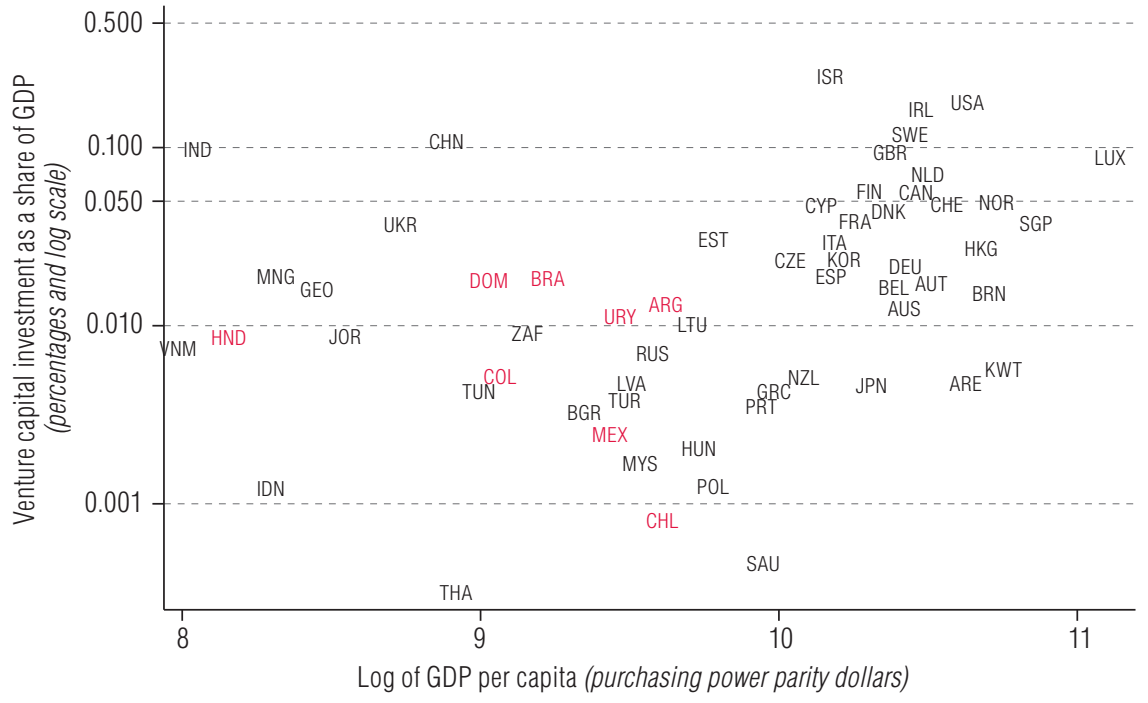


Figure 4 (concluded)

B. Using venture capital data from Thomson ONE, around 2011

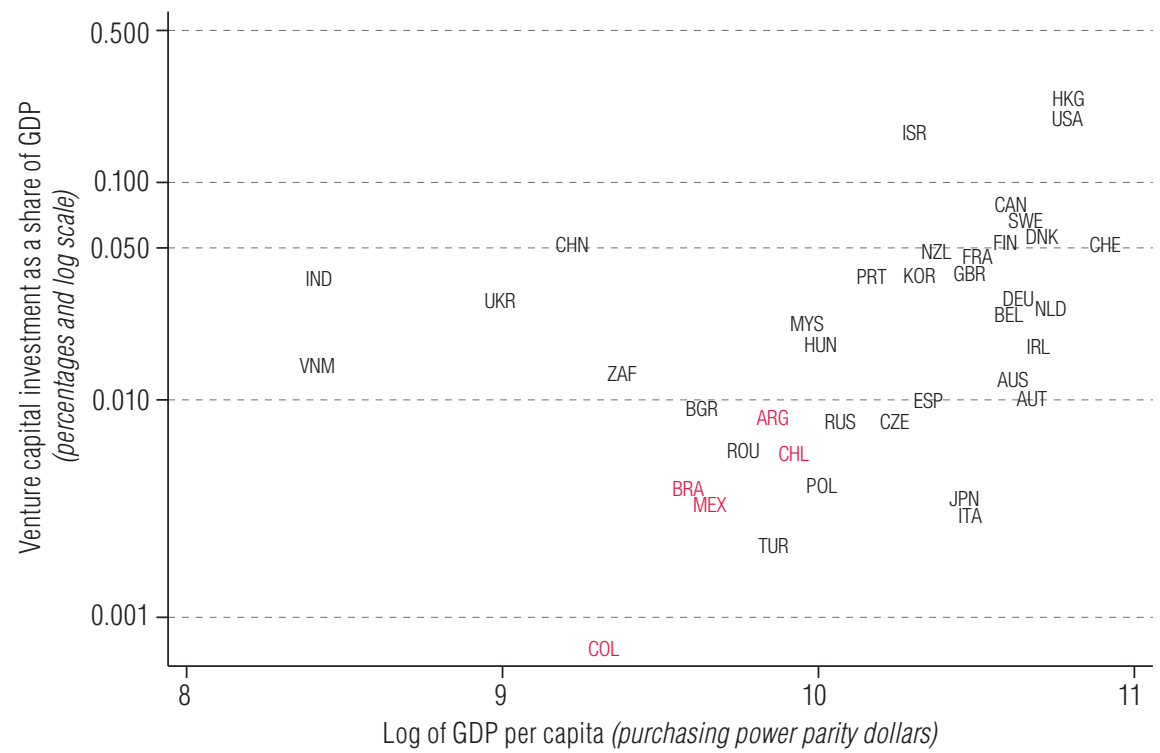

Source: Prepared by the authors, on the basis of J. Lerner, "Presentation of venture capital trends", paper presented at the Venture Capital in Latin American Policy Meeting, Inter-American Development Bank (IDB)/Multilateral Investment Fund, 17 May 2012, and data from Thomson ONE and World Bank, World Development Indicators [online database] https:// datacatalog.worldbank.org/dataset/world-development-indicators.

As expected, Latin American countries are behind global leaders such as the United States and Israel. Nonetheless, a striking but less obvious fact is that the average VC investment-to-GDP ratio for China and India is $0.04 \%$, but the average for the Latin American countries in the sample is just one tenth of this $(0.004 \%)$, even though the average per capita income of the Latin American countries is twice that of China and India (see figure 4.A). This qualitative result does not change significantly if weighted by the size of the countries in each group (in other words, if the Latin American countries in the sample are considered as a single entity). Most Latin American countries in this plot seem closer to some Eastern European economies, or even to more developed economies with lower relative $\mathrm{VC}$ penetration such as Italy, Spain or Japan. Although the relative positions of Latin American countries change in figure 4.B, which uses Thomson ONE data, the overall picture of the region and the comparison with China and India are strikingly similar.

China and India tend to invest more than other countries generally, not just in VC investments. For same years shown in figure 4, gross fixed capital formation was around $21 \%$ of GDP for the Latin American economies in the sample. The investment rate in China was twice that, close to $45 \%$ of GDP; while the rate in India was somewhere in between, around 33\% of GDP. That means that there is a difference in investment generally; but the tenfold difference in the VC-to-GDP ratio found by this study is only partially explained by this general investment trend. There is at least a fivefold "residual" lag in the Latin American VC-to-GDP ratio even after this correction. 
When comparing research and development (R\&D) investments in the same years as used for figure 4, the weighted average in Latin America is not far behind India's, at around $0.8 \%$ of GDP. ${ }^{10}$ In contrast, the rate of R\&D investment in China is twice as high as these figures, in the neighbourhood of $1.7 \%$ of GDP. Nonetheless, these differences in R\&D investment intensity do not fully explain the tenfold difference in VC investment between Latin America and China and India revealed by figures 4.A and 4.B. In short, the lag of Latin American venture capitalism vis-à-vis the large emerging Asian economies seems greater than expected, at least when considering macroeconomic investment rates or R\&D intensities.

It is worth noting that the goal of an economy is not to maximize venture capitalism; and, in fact many developed economies do not have high levels of $\mathrm{VC}$ financing. Having said that, an open question for the rest of this article would be whether levels of VC investment are low because there are few projects demanding VC financing (little "deal flow", maybe because of the type of innovation or industry in which the country in question has advantages) or because of the level of financial development. This point will be considered below in section $\mathrm{V}$.

\section{Comparative stylized facts on venture capitalism in Latin America and the Caribbean}

This section outlines various characteristics of VC investments in Latin America and the Caribbean, in comparison to those of other regions, especially the large Asian economies such as China and India.

\section{High-technology sectors account for a lower share of Latin American venture capital investments}

Figure 5 shows that $\mathrm{VC}$ investment rates in Latin America have been 5 percentage points lower than in other non-industrialized regions over the last decade. This trend can also be seen in specifications (4) and (5) of table 2, which show that the share of projects in high-technology sectors is smaller in Latin America and the Caribbean than in high-income and East Asian and Pacific countries (chiefly China). To check that the high-technology share does not reflect reporting bias, table 2 considers those transactions which report investment in (4), as well as those that do not in (5). The aforementioned differences in regional averages are qualitatively unaffected by the type of measurement, which suggests that that the high-technology sector's low share of investment in Latin America and the Caribbean is unlikely to stem from a bias in the value of reported transactions. Overall, roughly half of early-stage investments in the region are in high technology firms, compared to 75\% in East Asia (a figure that is almost the same as that of developed nations) and 60\% in South Asia. Only high-technology firms in the region of Eastern Europe and Central Asia (mostly composed of countries of the former Soviet Union) receive as little investment as those in Latin America, while those in Sub-Saharan Africa are at the very bottom of the ranking, with around $10 \%$.

Overall, the wealthier the country, the greater VC investments tend to be. This appears both in a worldwide cross-country correlation (not shown) and also within Latin American economies (see figure 6).

\footnotetext{
${ }^{10}$ Brazil spent more on R\&D relative to GDP than India, at around 1.1\% of GDP; while the rate is lower than that of India in Mexico, Chile and most of the other Latin American countries. See World Bank, World Development Indicators [online database] https:// datacatalog.worldbank.org/dataset/world-development-indicators for the year 2010-2011.
} 
Figure 5

Latin America and selected non-industrialized countries: the high-technology sector's share of venture capital transactions, 2000-2012

(Decimal fractions, 0-1)

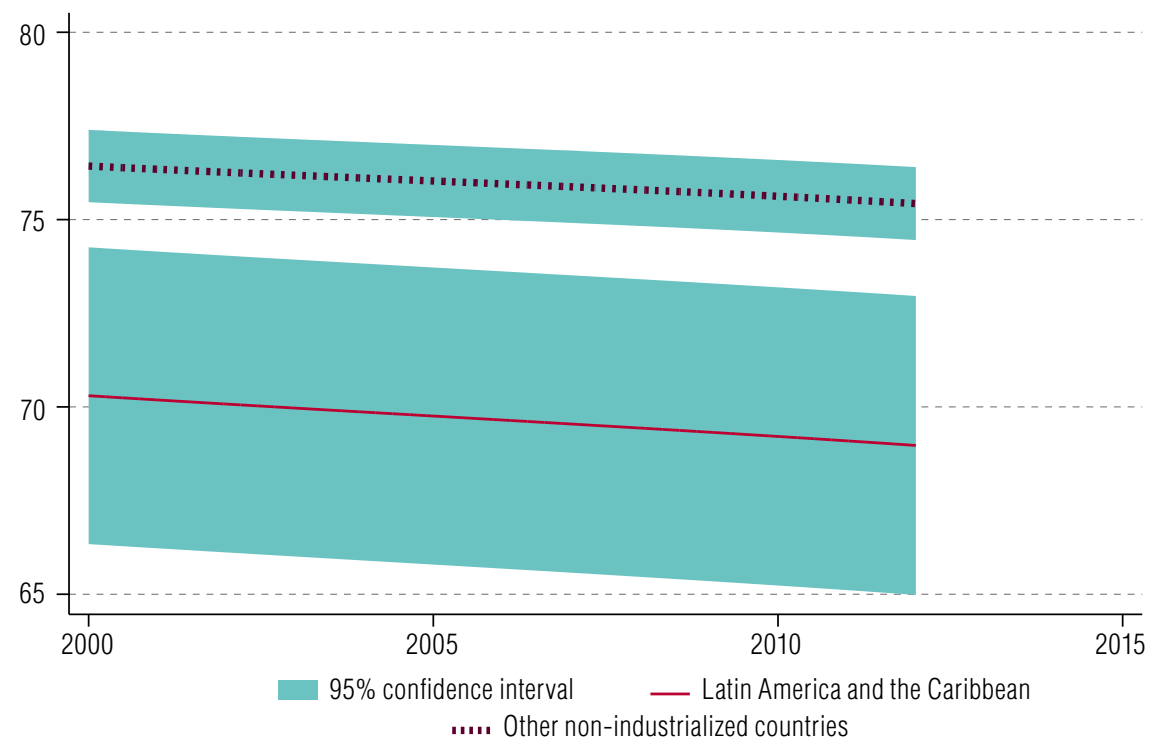

Source: Prepared by the authors.

Figure 6

Latin America (10 countries): ${ }^{a}$ the high-technology sector's share of venture capital transactions, by per capita GDP (At 2011 purchasing power parity (PPP), in logs)

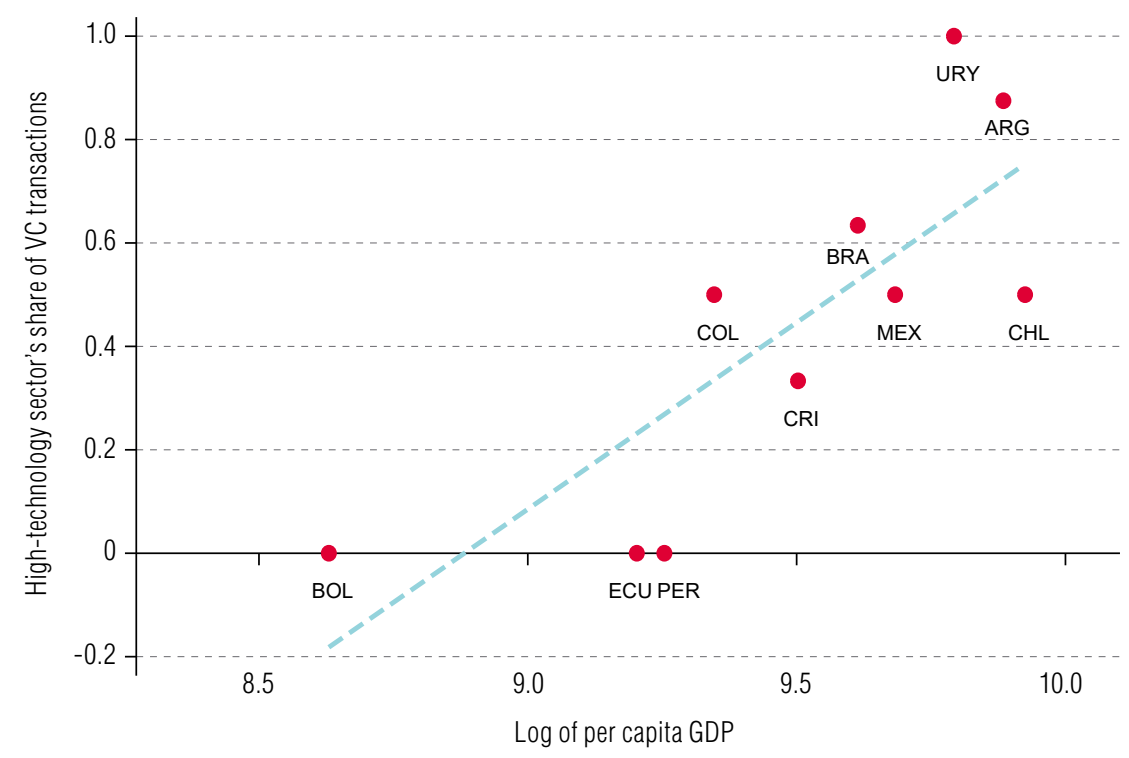

Source: Prepared by the authors, on the basis of data from Thomson ONE.

Note: Each log point of per capita GDP is associated with a 14 percentage point increase in the share of the high-technology sector. a Argentina, Brazil, Chile, Colombia,Costa Rica, Ecuador, Mexico, Peru, Plurinational State of Bolivia and Uruguay. 


\section{Venture capital investments in Latin America are larger on average than in comparable regions, but mostly go to non-high-technology firms}

Table 2 reports the average investment amounts by region. Column (1) shows that early-stage VC investments are larger in Latin America and the Caribbean than in developed and many other non-high-income regions, except for East Asia and the Pacific, which is mostly dominated by transactions in China. To understand the reasons for this, transactions are classified according to whether or not they are in the high-technology sector (2 and 3). The analysis reveals that the bulk of the difference for Latin America is caused by very large investments in non-technology sectors, which pushes up the average investment amount. This trend contrasts with the pattern in East Asia and the Pacific (chiefly China), where investment sizes are larger in both the high-technology and the other categories.

Table 2

World: regressions of venture capital investment size and share of high-technology firms on regional dummies ${ }^{a}$

\begin{tabular}{|c|c|c|c|c|c|}
\hline \multirow{3}{*}{ Region } & \multicolumn{3}{|c|}{ Left-hand side: log of investment } & \multicolumn{2}{|c|}{ Left-hand side: share of high-technology firms } \\
\hline & All & $\begin{array}{l}\text { If non-high- } \\
\text { technology }\end{array}$ & High-technology & $\begin{array}{l}\text { If reporting investment } \\
\text { (US dollars) }\end{array}$ & All \\
\hline & $(1)$ & (2) & (3) & (4) & (5) \\
\hline \multirow[t]{2}{*}{ East Asia and the Pacific } & $1.288^{\star \star \star}$ & $1.606^{\star \star \star}$ & $1.172^{\star \star \star}$ & $0.733^{\star \star \star}$ & $0.726^{\star \star \star}$ \\
\hline & $(0.02)$ & $(0.08)$ & $(0.02)$ & $(0.01)$ & $(0.00)$ \\
\hline \multirow[t]{2}{*}{ Eastern Europe and Central Asia } & 0.203 & 0.701 & -0.295 & $0.500^{\star \star}$ & $0.536^{\star \star \star}$ \\
\hline & $(0.35)$ & $(0.66)$ & $(0.25)$ & $(0.22)$ & $(0.14)$ \\
\hline \multirow[t]{2}{*}{ Industrialized countries } & $-0.579^{*}$ & $-0.733^{\star \star}$ & $-0.522^{*}$ & $0.728^{\star \star \star}$ & $0.727^{\star \star \star}$ \\
\hline & $(0.30)$ & $(0.31)$ & $(0.31)$ & $(0.03)$ & $(0.02)$ \\
\hline \multirow[t]{2}{*}{ Latin America and the Caribbean } & $1.373^{\star \star \star}$ & $2.655^{\star \star \star}$ & 0.0912 & $0.500^{\star \star \star}$ & $0.483^{\star \star \star}$ \\
\hline & $(0.22)$ & $(0.58)$ & $(0.28)$ & $(0.13)$ & $(0.10)$ \\
\hline \multirow[t]{2}{*}{ South Asia } & $0.682^{\star \star \star}$ & $1.079^{\star \star \star}$ & $0.418^{\star \star \star}$ & $0.600^{\star \star \star}$ & $0.634^{\star \star \star}$ \\
\hline & $(0.03)$ & $(0.04)$ & 0.00 & $(0.02)$ & $(0.01)$ \\
\hline \multirow[t]{2}{*}{ Sub-Saharan Africa } & -0.456 & -0.478 & -0.247 & $0.0952^{\star \star}$ & $0.0800^{\star \star}$ \\
\hline & $(0.41)$ & $(0.39)$ & $(1.69)$ & $(0.04)$ & $(0.04)$ \\
\hline No. of observations & 1818 & 520 & 1298 & 1818 & 2748 \\
\hline R-squared & 0.105 & 0.155 & 0.09 & 0.722 & 0.721 \\
\hline
\end{tabular}

Source: Prepared by the authors, on the basis of data from Thomson ONE.

Note: Robust standard errors clustered by country are given in parentheses. Asterisks indicate the statistical significance of the coefficient: ${ }^{* * *} p$-value $<0.01,{ }^{* \star} p$-value $<0.05,{ }^{*} p$-value $<0.1$.

a The Middle East and Africa is excluded because Thomson ONE data only cover seed and early-stage investments for that region. No group is omitted from the regression.

\section{In Latin America and the Caribbean, foreign venture capitalists invest larger amounts per round than domestic ones}

Figure 7 displays the distribution of transaction size by round and according to the nationality of the VC firm investing in the deal. On average foreign firms invest larger amounts. Figure 7.A shows that this is the case for seed and early-stage investments, while figure 7.B confirms that it is also the case with expansion and later-stage projects. These results, obtained using post-2005 data, are consistent with the previous findings of Khoury, Junkunc and Mingo (2012), who used pre-2004 data.

One potential concern is that the manner in which Thomson ONE data are collected could make it more likely that smaller transactions by foreign firms (many of which are based in the United States) are recorded. This potential bias, however, works contrary to the finding in figure 7 , making the 
case for an even higher average level of investment by foreign firms. Another potential concern with the aforementioned stylized fact is that in Latin America the share of investments made by foreign VC firms could be larger, for example, because of a favourable time-zone relative to the United States or for some other reason. Table 3 considers the share of investments made by domestic venture capitalists (in other words, the complement of foreign VC firms). Investment in Latin America does not appear to be particularly skewed towards foreign firms. Foreign VC firms account for a similar share of investment in the region of East Asia and the Pacific (which includes China) as in Latin America and the Caribbean. Investment in the region of South Asia, which includes India, is split roughly 50-50 between domestic and foreign venture capitalists. This is almost twice the share of foreign VC investment than East Asia and the Pacific or Latin America and the Caribbean.

\section{Figure 7}

Latin America and the Caribbean: investment rounds, by domestic or foreign venture capital investors, 2005-October 2012

(US dollars, in $\log 10$ )

A. All venture capital investments

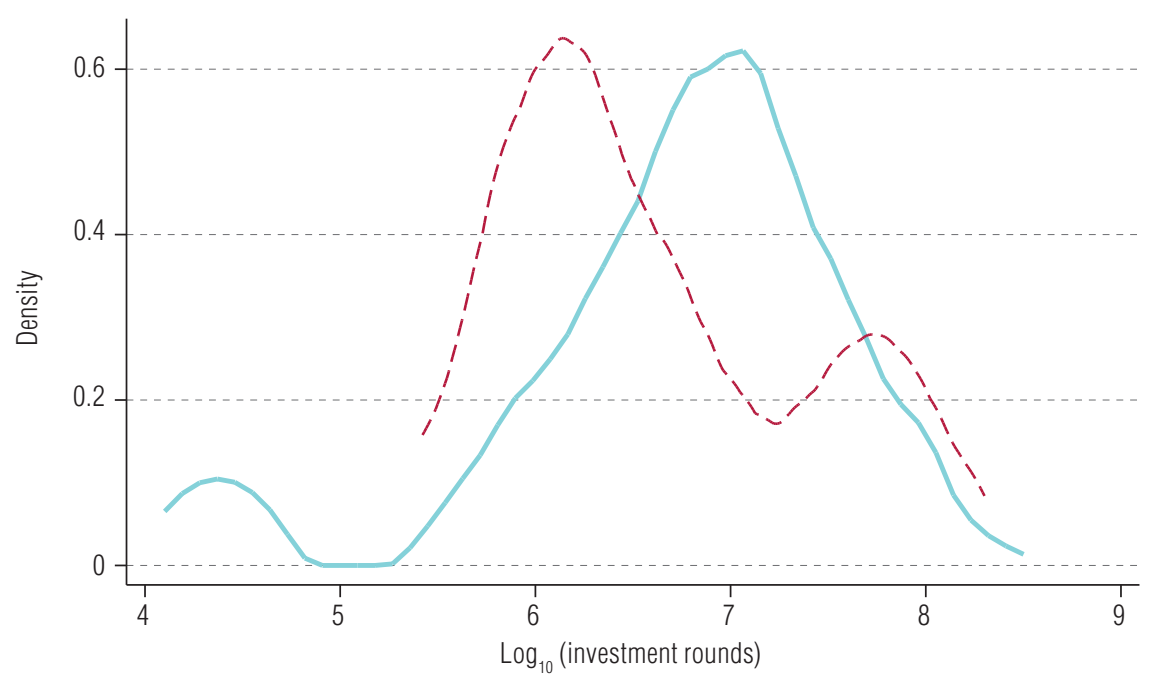

B. Seed and early-stage venture capital investments

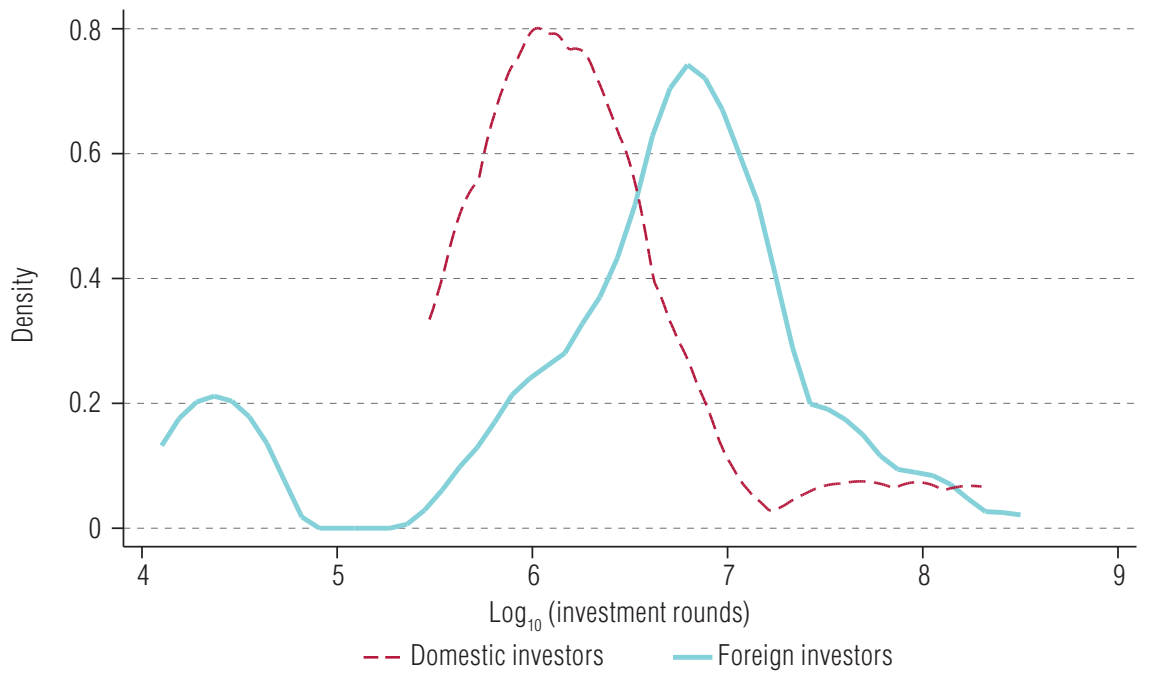

Source: Prepared by the authors, on the basis of data from Thomson ONE.

Note: The plots use company-round-firm observations to avoid overweighting syndicated deals. The t-tests of means confirm that VC investments by foreign venture capitalists are larger. 


\section{Venture capitalists investing in Latin America have less experience than those in comparable regions}

Venture capital has been described as an industry in which there is much to learn from experience and specialization. ${ }^{11}$ Unfortunately, VC firms investing in Latin America seem to have less experience. Table 3 shows that the average VC firm investing in Latin America is 12 years old, in sharp contrast to all other regions, where, on average, firms have between 18 and 20 years of experience. The only exception is Sub-Saharan Africa, where VC firms are even younger. To some extent, Latin American VC firms suffer from a problem similar to that noted by Hsieh and Klenow (2014), who show that most United States manufacturing jobs are created by firms with longer histories and probably more organizational capital than companies in Mexico.

It is important to note the magnitude. The VC firms investing in industrialized countries are in fact those with the greatest experience (around 21 years). Columns (3) and (4) show that firms investing in East Asia and the Pacific (which includes China) and in South Asia (including India) only have two or three years less experience than those in industrialized countries. In contrast, Latin American investments are made by firms that, on average, have half the experience of their counterparts in industrialized countries. Column (4) also explores whether the results depend on the share of investments made by domestic VC firms, using a dummy variable that considers the fact that domestic VC firms may have less experience. On average, a domestic VC firm has four years less experience. Nonetheless, the fact that Latin America lags behind other regions - except Sub-Saharan Africa - is robust to this additional control variable.

Table 3

World: regressions explaining the regional effects of the share of domestic venture capital investors and age of the firm, 2005-October 2012

\begin{tabular}{|c|c|c|c|c|}
\hline \multirow{3}{*}{ Region } & \multicolumn{2}{|c|}{ Left-hand side: binary 1 if VC is domestic } & \multicolumn{2}{|c|}{ Left-hand side: age of VC firm (years, } \\
\hline & $\begin{array}{l}\text { Reported investment } \\
\text { (US dollars) }\end{array}$ & All & $\begin{array}{l}\text { Reported investment } \\
\text { (US dollars) }\end{array}$ & All \\
\hline & $(1)$ & $(2)$ & (3) & (4) \\
\hline \multirow[t]{2}{*}{ East Asia and the Pacific } & $0.730^{\star \star \star}$ & $0.699^{\star \star \star}$ & $18.14^{\star \star \star}$ & $17.65^{\star \star \star}$ \\
\hline & $(0.01)$ & $(0.01)$ & $(0.27)$ & $(1.33)$ \\
\hline \multirow[t]{2}{*}{ Eastern Europe and Central Asia } & $0.563^{\star \star \star}$ & $0.500^{\star \star \star}$ & $18.47^{\star \star \star}$ & $18.01^{\star \star \star}$ \\
\hline & $(0.05)$ & $(0.05)$ & $(3.98)$ & $(2.32)$ \\
\hline \multirow[t]{2}{*}{ Industrialized countries } & $0.847^{\star \star \star}$ & $0.864^{\star \star \star}$ & $20.56^{\star \star \star}$ & $21.81^{\star \star \star}$ \\
\hline & $(0.03)$ & $(0.02)$ & $(1.45)$ & $(1.07)$ \\
\hline \multirow[t]{2}{*}{ Latin America and the Caribbean } & $0.778^{* \star *}$ & $0.760^{\star \star *}$ & $12.95^{\star \star \star}$ & $11.96^{\star \star \star}$ \\
\hline & $(0.22)$ & $(0.17)$ & (4.42) & (2.14) \\
\hline \multirow[t]{2}{*}{ South Asia } & $0.535^{\star \star \star}$ & $0.547^{\star \star \star}$ & $20.54^{\star \star \star}$ & $21.74^{\star \star \star}$ \\
\hline & $(0.02)$ & $(0.01)$ & $(0.33)$ & $(1.03)$ \\
\hline \multirow[t]{2}{*}{ Sub-Saharan Africa } & $0.619^{\star \star \star}$ & $0.560^{\star \star \star}$ & $7.840^{\star \star \star}$ & $12.35^{\star \star \star}$ \\
\hline & $(0.17)$ & $(0.15)$ & (2.93) & $(3.07)$ \\
\hline \multirow[t]{2}{*}{$1\{$ Domestic VC\} } & & & & $-4.84^{\star \star \star}$ \\
\hline & & & & $(1.71)$ \\
\hline No. of observations & 1562 & 2424 & 1810 & 2415 \\
\hline R-squared & 0.828 & 0.842 & 0.566 & 0.498 \\
\hline
\end{tabular}

Source: Prepared by the authors, on the basis of data from Thomson ONE.

Note: The benchmark is Middle East (no intercept). The dummy variable 1\{Domestic VC\} takes the value one for domestic VC and zero otherwise. Subsample only includes seed and early-stage projects from Thomson ONE. Robust standard errors clustered by country are given in parentheses. Asterisks indicate the statistical significance of the coefficient: ${ }^{\star \star \star} p$-value $<0.01,{ }^{\star \star}{ }^{*}$-value $<0.05,{ }^{*} p$-value $<0.1$.

\footnotetext{
11 Gompers, Kovner and Lerner (2009) note that the experience and focus of a firm's board members are what matters most for returns. Although that measure is not available, it might be reasonable to assume that in less developed economies VC firms are small, so the age of the firm might be a proxy for individual board members' skills. See Gompers and Lerner (2004) for additional information.
} 


\section{Venture capital investments in Latin America and the Caribbean are highly procyclical}

In most countries around the world, investment tends to be procyclical with respect to the business cycle. This subsection explores the differential characteristics of venture capital investments.

Table 4 reports estimates of the procyclicality of VC investments at the country level, over the period 2000-2011. The estimations are made using an unbalanced panel data regression, with country fixed effects, where the percentage change in VC investments is explained by GDP growth and a linear trend. The coefficient on GDP growth, referred to as the cyclicality coefficient, is used in fiscal literature to determine whether these types of investment are procyclical with respect to overall economic activity (a positive coefficient) or countercyclical (a negative coefficient). Column (1) shows that for Latin American countries, post-2000 VC investments seem highly procyclical, with a coefficient of 19 . This means that, on average, when the economy as a whole grows $1 \%$ faster than average, the VC dollars invested in the country grow by $19 \%$ more than average.

Table 4

Procyclicality regressions: changes in investment relative to changes in per capita GDP

\begin{tabular}{|c|c|c|c|c|c|c|}
\hline \multirow{3}{*}{ Variables } & \multicolumn{3}{|c|}{ Latin America and the Caribbean ${ }^{\mathrm{a}}$} & \multicolumn{3}{|c|}{ All other regions of the world ${ }^{b}$} \\
\hline & $\Delta \%$ VC \$ & $\Delta \%$ VC N & $\Delta \%$ GFCF & $\Delta \%$ VC \$ & $\Delta \%$ VC N & $\Delta \% \mathrm{GFCF}$ \\
\hline & (1) & (2) & (3) & (4) & (5) & (6) \\
\hline \multirow[t]{2}{*}{ Cyclicality ( $\triangle \%$ GDP) } & $19.02^{\star \star}$ & $9.636^{*}$ & $6.131^{\star \star \star}$ & 3.213 & $3.408^{\star \star}$ & $4.35^{\star \star \star}$ \\
\hline & $(6.15)$ & $(4.52)$ & $(0.51)$ & $(3.56)$ & (1.35) & $(0.35)$ \\
\hline \multirow[t]{2}{*}{ Trend (year) } & 0.00889 & -0.0214 & 0.00162 & $0.0323^{*}$ & $-0.0133^{\star}$ & $0.007^{\star \star \star}$ \\
\hline & $(0.04)$ & $(0.02)$ & $(0.01)$ & $(0.02)$ & $(0.01)$ & $(0.00)$ \\
\hline No. of observations & 37 & 37 & 37 & 530 & 530 & 514 \\
\hline R-squared & 0.321 & 0.205 & 0.805 & 0.008 & 0.027 & 0.497 \\
\hline No. of Country FE & 9 & 9 & 9 & 83 & 83 & 80 \\
\hline
\end{tabular}

Source: Prepared by the authors, on the basis of World Bank, World Development Indicators [online database] https://datacatalog. worldbank.org/dataset/world-development-indicators.

Note: Robust standard errors clustered by country are given in parentheses. Asterisks indicate the statistical significance of the coefficient: ${ }^{* \star} p$-value $<0.01,{ }^{\star \star} p$-value $<0.05,{ }^{*} p$-value $<0.1$.

a Argentina, Bahamas, Brazil, Chile, Colombia, Mexico, Panama, Trinidad and Tobago, and Uruguay.

b Excluding the United States and Canada.

All panel regressions are in the form:

$$
\Delta \% y=\beta \Delta \% G D P+\gamma \text { Time Trend }+ \text { Country FE }
$$

Columns (1) and (4) use the percentage change in the total amount of VC investment ( $\triangle \% \mathrm{VC} \$$ ) on the left-hand side. Columns (2) and (5) use the change in the number of projects ( $\triangle \% \mathrm{VCN}$ ). Columns (3) and (6) are benchmarks using changes in gross fixed capital formation (GFCF) from the national accounts as measure of macroeconomic investment. For comparability, the exercise is performed for the same years and countries for which data are available on VC investments, including the value and number of projects. Columns (4) to (6) perform the same regressions as in (1) to (3) but for all countries of the world that are included in the Thomson ONE data, with the exception of the United States and Canada, which were excluded in order to obtain a global comparison that was not skewed by data from these highly innovative countries where VC is more developed.

It is well known in the macroeconomics literature that investment is procyclical, but the estimates reported in column (1) of table 4 indicate that VC is significantly more procyclical than macroeconomic investment in general. As a benchmark, column (3) computes the procyclicality of gross fixed capital formation. This macroeconomic investment displays a procyclicality coefficient of 6.1 in the same sample of Latin American countries and years used in figure 6. 
This means that $\mathrm{VC}$ is three times more procyclical than macroeconomic investment. Nonetheless, models (1) and (3) are not nested, so it is impossible to test directly for the difference in procyclicality, but it is safe to say that Latin American VC seems more procyclical than investment in general.

The worldwide VC cyclicality coefficient is just 3.2; well below the 19 recorded for Latin America. Importantly, the difference between Latin America and the worldwide sample seems much higher for VC investment ((1) minus (4) gives a difference of 15 units but with a large standard error) than for macroeconomic capital formation ((3) minus (6) indicates a gap of just 1 to 2 units).

Columns (2) and (5) explore the cyclical sensitivity of the extensive margin, that is the number of VC projects recorded in the database. The point estimate for Latin America is 9.6, almost three times the equivalent for the worldwide sample (column (4)); in other words, the sample of VC investments in the Latin American region depicts a remarkably cyclical pattern, with a portion coming from the number of projects and another stemming from average project size.

Another regression (not shown) analogous to (2) but using the number of projects reporting transaction values produces a very similar procyclicality coefficient. This suggests that partial recording of investment size might not be the main cause of the high level of procyclicality in Latin America.

Excluding the year 2000 from the sample does not qualitatively change the results for Latin America except that it increases the standard error for the coefficient of GDP growth in the $\triangle \% \mathrm{VC} \mathrm{N}$ specification, since it has a p-value slightly above $10 \%$.

With regard to the rest of the world, specifications (4) and (5) become less procyclical and insignificant when 2000 is excluded for the worldwide regressions. But since that is the benchmark group for this study, the qualitative claim that Latin America seems more procyclical becomes even stronger.

To summarize, the Latin American pattern of VC investment is highly correlated with the domestic business cycle. In a context of volatile economic growth, this procyclicality is a further complication for firms wishing to specialize in venture capital, since in harder times investment of this type retreats much more quickly from a Latin American country than from an average country in the rest of the world.

\section{Venture capital: chasing ideas or following financial development?}

This final empirical section explores the determinants of variations in VC development among countries, dividing the explanatory factors into two groups. One category consists of demand for VC arising from scientific and technological ideas, proxied by patents and scientific articles. The other contains a standard indicator of financial development used in the literature (for example Rajan and Zingales, 1997), measured as stock market capitalization relative to GDP. The latter measures the availability of funds, not for VC, but for a larger portion of the financial system. The idea is to test whether factors driving demand for VC (ideas), or the supply of finance, have empirical traction in explaining different VC patterns of development among countries. In the regression, we also control for country size (GDP), splitting this into per capita income and population.

Table 5 shows the estimates for factors that could explain the VC-to-GDP ratio. These are: In(patents/pop), which represents the number of patent applications by residents per capita; In(articles/pop), which denotes the number of scientific articles by residents per capita; In(GDP), which is the country's GDP in PPP terms. This is then split into a per capita income term and a population term, namely In(GDP/pop) and In(population). The variable In(market cap) corresponds to the usual sum of stock market capitalization of listed companies in the country, as a proportion of GDP. 
Table 5

Venture capital development

\begin{tabular}{|c|c|c|c|c|c|c|c|c|}
\hline \multirow{2}{*}{$\begin{array}{l}\text { Variables, } \\
\text { around } 2011\end{array}$} & \multicolumn{8}{|c|}{ Left-hand side variable: In(VC/GDP) in the country, 2010-2011 } \\
\hline & (1) & (2) & (3) & (4) & (5) & (6) & (7) & $\begin{array}{c}\text { Mean } \\
\text { (standard deviation) }\end{array}$ \\
\hline \multirow[t]{2}{*}{ In(patents/pop) } & $0.44^{\star *}$ & $0.41^{\star \star \star}$ & $0.36^{\star \star \star}$ & $0.43^{\star \star}$ & $0.40^{\star \star \star}$ & & & -9.89 \\
\hline & $(0.19)$ & $(0.12)$ & $(0.12)$ & $(0.16)$ & $(0.12)$ & & & $(1.89)$ \\
\hline \multirow[t]{2}{*}{ In(sci articles/pop) } & & & & & & & $0.84^{\star \star \star}$ & -8.90 \\
\hline & & & & & & & $(0.24)$ & $(1.72)$ \\
\hline \multirow[t]{2}{*}{ In(market cap/GDP) } & 0.11 & 0.10 & -0.19 & -0.55 & & 0.19 & -0.53 & 3.57 \\
\hline & $(0.23)$ & $(0.22)$ & $(0.58)$ & $(0.52)$ & & $(0.22)$ & $(0.51)$ & $(1.09)$ \\
\hline \multirow[t]{2}{*}{ In(market cap/GDP) ${ }^{2}$} & & & 0.07 & 0.06 & & & 0.07 & \\
\hline & & & $(0.09)$ & $(0.08)$ & & & $(0.08)$ & \\
\hline \multirow[t]{2}{*}{$\ln (G D P)$} & & -0.07 & $-8.44^{\star *}$ & & & & & 26.52 \\
\hline & & $(0.16)$ & $(3.85)$ & & & & & (1.54) \\
\hline \multirow[t]{2}{*}{$\ln (G D P)^{2}$} & & & $0.16^{\star \star}$ & & & & & \\
\hline & & & $(0.07)$ & & & & & \\
\hline \multirow[t]{2}{*}{ In(GDP/pop) } & -0.17 & & & $-16.5^{\star \star \star}$ & & & $-14.8^{* * *}$ & 9.65 \\
\hline & $(0.44)$ & & & $(3.82)$ & & & $(3.68)$ & $(0.91)$ \\
\hline \multirow[t]{2}{*}{$\ln (G D P / p o p)^{2}$} & & & & $0.89^{\star \star \star}$ & & & $0.77^{\star \star \star}$ & \\
\hline & & & & $(0.21)$ & & & $(0.20)$ & \\
\hline \multirow[t]{2}{*}{ In(population) } & -0.07 & & & $-3.62^{*}$ & & & $-5.02^{\star \star \star}$ & 16.87 \\
\hline & $(0.16)$ & & & $(1.85)$ & & & $(1.79)$ & $(1.62)$ \\
\hline \multirow[t]{2}{*}{$\ln (\text { population) })^{2}$} & & & & $0.11^{\star \star}$ & & & $0.15^{\star \star \star}$ & \\
\hline & & & & $(0.05)$ & & & $(0.05)$ & \\
\hline \multirow[t]{2}{*}{ Constant } & 2.37 & 0.95 & $111.4^{\star *}$ & $106.6^{\star \star \star}$ & -0.51 & $-5.1^{\star \star \star}$ & $116.08^{\star \star \star}$ & \\
\hline & (7.16) & $(4.53)$ & (50.83) & (21.76) & $(1.16)$ & $(0.82)$ & (21.36) & \\
\hline \multirow[t]{2}{*}{$\log (\mathrm{VC} / \mathrm{GDP})$} & & & & & & & & -4.47 \\
\hline & & & & & & & & (1.84) \\
\hline No. of countries & 61 & 61 & 61 & 61 & 61 & 61 & 60 & 61 \\
\hline R-squared & 0.17 & 0.17 & 0.25 & 0.45 & 0.17 & 0.01 & 0.50 & \\
\hline
\end{tabular}

Source: Prepared by the authors, on the basis of data from Thomson ONE and World Bank, World Development Indicators [online database] https://datacatalog.worldbank.org/dataset/world-development-indicators.

Note: Robust standard errors clustered by country are given in parentheses. Asterisks indicate the statistical significance of the coefficient: ${ }^{* \star}{ }^{*} p$-value $<0.01,{ }^{* \star} p$-value $<0.05,{ }^{*} p$-value $<0.1$.

In all specifications (1) to (7) technical and scientific ideas are a robust predictor of VC development. Depending on the specification, a 1 percentage point increase in patents per capita is associated with a 0.4-point increase in the VC-to-GDP ratio. Specification (7) shows that a 1-point increase in scientific articles per capita is associated with a 0.8 of a percentage point increase in the VC-to-GDP ratio. Only one of these measures can be used at a time, however, because they are highly correlated (0.84).

In contrast, all specifications show that the standard financial development variable does not explain VC development differences among countries. Specifications (1) to (4) and (6) to (7) all report statistically non-significant coefficients for the standard financial development coefficient. This continues even with nonlinear specifications for market capitalization (columns 3, 4 and 7) or when used as a single explanatory variable (column 6).

The results suggest that the demand for VC stemming from technical ideas is a relevant indicator and better at explaining VC intensity around the world. Venture capital grows when there are ideas, not when there is simply a high stock valuation.

Table 5 also includes controls for other obvious effects, such as market size. Column (2) controls for the log of total GDP, while column (1) splits this covariate into two separate components: per capita income and population. Neither of these specifications finds statistical significance for these market-size effects. The reason seems to be that the response of market-size variables is nonlinear. In fact, column (3) 
shows that log of total GDP has a positive and statistically significant quadratic term. In practice, given the averages in the right-hand column of table 5 , this means the effect of size has the shape of a J-curve in VC development. This is also confirmed when non-parametric methods are used (not shown in the table). Columns (4) and (7) include quadratic components for the subcomponents of total GDP, namely per capita income and population, in log form. These regressions also suggest a J-shaped curve, which means that $\mathrm{VC}$ investments tend to be disproportionally larger in very large economies. ${ }^{12}$

The regression analysis performed in this study seems to indicate the relevance of both market size and technology ideas in driving the demand for VC. Using the coefficient estimated in column (5), and multiplying it by the difference in patenting rates between China and the average for Latin America and the Caribbean, we can account for a third of the gap in VC-to-GDP ratio with China, evident in figure 4.A. ${ }^{13}$ In that regard, Ketelhöhn and Ogliastri (2013) argue that Latin America has low levels of patenting and innovation; the present study finds that this deficit of technology and scientific ideas could pose a bottleneck for further VC development in the region.

Nonetheless, as noted above, patenting rates are far from the only factor. Table 5 clearly shows that market size matters. Using the model in column (3) indicates that at least a third of the VC gap between China and the average for Latin America and the Caribbean can be more readily explained by size-related variables, rather than patenting rates. ${ }^{14}$ Market size is important not because the factors impeding VC development would be resolved as Latin America becomes wealthier, nor because the region needs faster population growth. Instead, the issue is that Latin American integration remains a major challenge for entrepreneurs. Despite the near-zero tariff barriers on trade across Latin America, it seems that the region has not achieved enough market integration to offer sufficiently large opportunities for innovative businesses demanding VC. In an ideal world, entrepreneurs in any Latin American market could think of ideas that could be replicated throughout the region as part of the same firm, as happens in China or even the United States.

\section{Concluding remarks}

This article examined the main trends in VC investments in Latin America, compared to other regions of the world. It finds that VC investments in Latin America and the Caribbean are growing very rapidly, outpacing nearly every other region in the world, although starting from a very low base.

The paper has highlighted various stylized facts about VC in the region, which are consistent with a VC ecosystem in its initial stages. First, the share of high-technology investments in the region is smaller than in other non-industrialized countries. Second, VC investments in Latin America are on average larger than in other regions of a similar income level but tend to take the form of non-high-technology investments. Third, foreign venture capitalists invest higher amounts in Latin America per round than domestic VC firms. ${ }^{15}$ This is consistent with a selection model, where foreign firms participate only if the deals are, on average, large enough to absorb the international transaction costs, or when foreign VC

\footnotetext{
12 Regressions that restrict the sample to countries with per capita incomes equal to, or above, those of India or Viet Nam do not produce qualitatively different results.

${ }^{13}$ Column (5) uses log(patents/population) as the only covariate and computes the residuals after fitting the model. The leftover portion after accounting for the patenting gap between China and the average for Latin America and the Caribbean is $37 \%$. The residual difference between the average patenting rate in Latin America and the Caribbean and that of China is $63 \%$ of the original difference, meaning that $37 \%$ of the proportional gap can be explained by this channel.

${ }^{14}$ Column (3) uses a specification including nonlinear economy size. This model explains $73 \%$ of the proportional gap between Latin America and the Caribbean and China. In short, roughly one third of the gap is explained by size, another third by patenting and a third remains unexplained. Including market capitalization in column (3) is innocuous, since the coefficients are small and insignificant, which means they have a negligible impact on this accounting exercise. Doing a similar exercise with a model like the one shown in column (3), but excluding market size, yields similar results (not shown here for brevity).

15 There is still a role for the local investor in attracting foreign venture capital (see for example Mäkelä and Maula, 2008).
} 
firms are more productive (see Helpman, Melitz and Yeaple, 2004). Fourth, VC firms in Latin America are younger and less experienced than in other regions. This is important, because experience is a key factor in explaining VC firms' performance and fundraising ability (Gompers and Lerner, 2004). Fifth, VC investments in the region are highly procyclical, more so than the VC procyclicality in other regions, and also more procyclical than macroeconomic investment in Latin America and the Caribbean.

Lastly, the paper has explored the variation in VC development among countries, attempting to disentangle why countries with much lower levels of development, such as China, have a much more highly developed VC market, given that stock markets do not follow this development trend. A regression of the $\mathrm{VC}$-to-GDP ratio shows that the production of patentable ideas is a strong predictor of VC investment, while a standard measure of financial development (stock market capitalization) fails to explain the variation among countries. More importantly, VC investments as a share of GDP are shown to be disproportionately bigger in larger markets. This calls for greater de facto integration of entrepreneurial business models in Latin America, to enable venture capitalists to detect regional potential for expansion. Overall, the findings of this study suggest that Latin America is in an early stage of VC development.

\section{Bibliography}

Bruton, G., D. Ahlstrom and T. Puky (2009), "Institutional differences and the development of entrepreneurial ventures: a comparison of the venture capital industries in Latin America and Asia", Journal of International Business Studies, vol. 40, No. 5, New York, Springer.

Cumming, D. and Y. Zhang (2016), "Alternative investments in emerging markets: a review and new trends", Emerging Markets Review, vol. 26, Amsterdam, Elsevier.

Gompers, P. and J. Lerner (2004), The Venture Capital Cycle, Cambridge, MIT Press.

Gompers, P., A. Kovner and J. Lerner (2009), "Specialization and success: evidence from venture capital", Journal of Economics \& Management Strategy, vol. 18, No. 3, Hoboken, Wiley.

Helpman, E., M. Melitz and S. Yeaple (2004), "Export versus FDI with heterogeneous firms", The American Economic Review, vol. 94, No. 1, Nashville, American Economic Association.

Hsieh, C. and P. Klenow (2014), "The life cycle of plants in India and Mexico", Quarterly Journal of Economics, vol. 129, No. 3, Oxford, Oxford University Press.

Jiménez, L. (2008), "Venture capital and innovation in Latin America”, CEPAL Review, No. 96 (LC/G.2396-P), Santiago, Economic Commission for Latin America and the Caribbean (ECLAC).

Ketelhöhn, N. and E. Ogliastri (2013), "Introduction: innovation in Latin America", Academia. Revista Latinoamericana de Administración, vol. 26, No. 1, Bingley, Emerald.

Khoury, T., M. Junkunc and S. Mingo (2012), "Navigating political hazard risks and legal system quality: venture capital investments in Latin America", Journal of Management, vol. 41, No. 3, Thousand Oaks, SAGE.

LAVCA (Latin America Private Equity and Venture Capital Association) (2012), "First database of private equity investments in Latin America".

Lerner, J. (2012), "Presentation of Venture Capital Trends", paper presented at the Venture Capital in Latin American Policy Meeting, Inter-American Development Bank (IDB)/Multilateral Investment Fund, May 17 th.

Liao, W., C. Lu and H. Wang (2014), "Venture capital, corporate governance, and financial stability of IPO firms", Emerging Markets Review, vol. 18, Amsterdam, Elsevier.

Mäkelä, M. and M. Maula (2008), "Attracting cross-border venture capital: the role of a local investor", Entrepreneurship \& Regional Development, vol. 20, No. 3, Abingdon, Taylor \& Francis.

Otchere, I. and A. Vong (2016), "Venture capitalist participation and the performance of Chinese IPOs", Emerging Markets Review, vol. 29, Amsterdam, Elsevier.

Pereiro, L. (2001), "Tango and cash: entrepreneurial finance and venture capital in Argentina", Venture Capital, vol. 3, No. 4, Abingdon, Taylor \& Francis.

Rajan, R. (2012), "The corporation in finance", NBER Working Paper, No. 17760, Cambridge, Massachusetts, National Bureau of Economic Research (NBER).

Rajan, R. and L. Zingales (1998), "Financial dependence and growth", The American Economic Review, vol. 88, No. 3, Nashville, American Economic Association. 


\section{Annex A1}

\section{Additional description of the sample}

\section{Thomson ONE VC data}

The private equity module of the Thomson ONE database includes different types of private equity investments, namely venture capital, buyouts and acquisitions, real estate and other. This paper focuses on VC investments only, which comprise seed, early stage, expansion and later stage investments. This study covers all of them, except where explicitly mentioned in each table. Each stage of investment is defined according to the criteria used by Thomson ONE. These criteria include, among other things, the investing fund, the company being invested in and the timing. The structure of the deal also helps to distinguish VC investments from non-venture capital ones. Given the nature of private equity, part of this classification is based on the self-reported activity of VC firms.

The venture capital subcomponent of the Thomson ONE private equity module is the successor of an earlier database, known as VentureXpert, which was used in previous analysis in the literature (see Gompers and Lerner, 2004). In short, these are standard data used in the academic literature on VC investments.

The specific sample used in this study spans 2000 to October 2012. Yearly analyses were used only up to 2011, which was the last complete year for which data are available; and most of the analysis in the various tables and figures uses post-2005 data. ${ }^{16}$ The investments in the sample cover nearly all industry categories, according to the Standard Industrial Classification (SIC). When investments are broken down by industry sector, just over $80 \%$ of transactions were in the following sectors: SIC 73 (business services), which accounted for $41 \%$ of all deals; SIC 28 (chemicals and allied products, including pharmaceuticals), with 11\%; SIC 36 (electronic and other electrical equipment, except computers), with 10.9\%; SIC 38 (instruments and related products), with 8.4\%; SIC 87 (engineering and management services) with 5.2\%; and SIC 48 (communications) with 4.1\%. The other sectors account for less than $3 \%$ of investments. ${ }^{17}$ Thomson ONE also uses another industry classification for VC investments that can be used to distinguish between high-technology and non-high technology industries. ${ }^{18}$

Table A1.1 displays the main descriptive statistics of Thomson ONE. The median firm in the sample received US\$ 3.5 million in a round, but in the first round the median firm received US\$2.6 million. The median firm received two rounds of financing. At the country level, the unweighted average VC investment is equivalent to $0.04 \%$ of GDP, while total investment in an average country is around $23 \%$ of GDP.

\footnotetext{
${ }^{16}$ The following countries are included in the sample: Argentina, Australia, Austria, Belgium, Brazil, Bulgaria, Canada, Chile, China, Colombia, Croatia, Cyprus, Czechia, Denmark, Egypt, Estonia, Finland, France, Georgia, Germany, Greece, Hong Kong Special Administrative Region, Hungary, India, Indonesia, Ireland, Israel, Italy, Japan, Jordan, Kenya, Latvia, Lithuania, Luxembourg, Malaysia, Mexico, Mongolia, Netherlands, New Zealand, Norway, Pakistan, Peru, Poland, Portugal, Republic of Korea, Russian Federation, Saudi Arabia, Singapore, South Africa, Spain, Sweden, Switzerland, Thailand, Tunisia, Turkey, Uganda, Ukraine, United Kingdom, United States, Uruguay and Viet Nam.

17 The SIC system classifies industries using a four-digit code. The first two digits represent the industry sector, and when the data are disaggregated by these first two digits, it reveals that VC investments were made in nearly all the 99 industry sectors classified in the SIC system. There are observations in the data for the 2000-2012 period in the following two-digit SIC codes: $10,12,13,14,15,16,17,20,21,22,23,24,25,26,27,28,29,30,31,32,33,34,35,36,37,38,39,40,41,42,43,44$, $45,46,47,48,49,50,51,52,53,54,55,56,57,58,59,60,61,62,63,64,65,67,70,72,73,75,76,78,79,80,81,82$, $83,84,86,87,88,89,91,92,93,94,95,96$ and 97 . Syndicated investments appear as often as partners in these descriptive statistics. This issue is appropriately resolved in the main tables of the paper.

18 The sector composition of the Thomson Reuters Venture Capital Index is: healthcare related; communications; biotechnology; semiconductor and electronics; computer software-; non-high-technology. All but the last of these are high-technology sectors.
} 
Table A1.1

Additional descriptive statistics, 2000-October 2012

\begin{tabular}{|c|c|c|c|c|c|c|}
\hline Variable & Mean & $\begin{array}{c}\text { Tenth } \\
\text { percentile }\end{array}$ & $\begin{array}{l}\text { Twenty-fifth } \\
\text { percentile }\end{array}$ & $\begin{array}{c}\text { Fiftieth } \\
\text { percentile }\end{array}$ & $\begin{array}{l}\text { Seventy-fifth } \\
\text { percentile }\end{array}$ & $\mathrm{N}^{\mathrm{a}}$ \\
\hline \multicolumn{7}{|l|}{ Microdata } \\
\hline Equity invested (millions of dollars) & 10.4 & 0.3 & 1.0 & 3.5 & 10.0 & 61833 \\
\hline Investment round & 2.6 & 1 & 1 & 2 & 3 & 87756 \\
\hline Equity invested in first round (millions of dollars) & 9.3 & 0.3 & 0.9 & 2.6 & 7.3 & 27918 \\
\hline \multicolumn{7}{|l|}{ Country-level aggregates } \\
\hline VC investments (percentages of GDP) & $0.04 \%$ & $0.00 \%$ & $0.00 \%$ & $0.02 \%$ & $0.05 \%$ & 61 \\
\hline $\begin{array}{l}\text { Gross fixed capital formation } \\
\text { (percentages of GDP) }\end{array}$ & $23.17 \%$ & $16.11 \%$ & $19.42 \%$ & $21.76 \%$ & $25.00 \%$ & 59 \\
\hline High-technology investments & $64.91 \%$ & $0.00 \%$ & $50.00 \%$ & $70.09 \%$ & $88.89 \%$ & 57 \\
\hline Syndicated investments & $50.47 \%$ & $0.00 \%$ & $0.00 \%$ & $47.33 \%$ & $95.73 \%$ & 56 \\
\hline Domestic VC investor & $49.82 \%$ & $0.00 \%$ & $4.17 \%$ & $50.00 \%$ & $84.06 \%$ & 56 \\
\hline
\end{tabular}

Source: Prepared by the authors, on the basis of data from Thomson ONE.

a For the microdata, $\mathrm{N}$ is the number of investments made by VC firms (excluding the United States); whereas, for the countrylevel aggregates, $\mathrm{N}$ is the number of countries in the group that are included in the estimation sample shown in table 5 . The inclusion of figures for the United States in the microdata does not change these broad averages significantly.

Table A1.2 shows the whole VC matrix by industry and country for the sample in Latin America and the Caribbean. Of the 773 projects, around half are non-high-technology projects. In terms of country distribution, $60 \%$ of VC investments in the region occur in Brazil.

Table A1.2

Latin American and the Caribbean (27 countries): VC investments by industry and country, 2000-October 2012

\begin{tabular}{|c|c|c|c|c|c|c|c|}
\hline Country & $\begin{array}{l}\text { Healthcare } \\
\text { related }\end{array}$ & Communications & Biotechnology & $\begin{array}{l}\text { Semiconductor } \\
\text { and electronics }\end{array}$ & $\begin{array}{l}\text { Computer } \\
\text { software }\end{array}$ & $\begin{array}{l}\text { Non-high- } \\
\text { technology }\end{array}$ & Total \\
\hline Antigua and Barbuda & 0 & 1 & 0 & 0 & 1 & 1 & 3 \\
\hline Argentina & 1 & 7 & 1 & 0 & 36 & 11 & 56 \\
\hline Bahamas & 0 & 0 & 0 & 0 & 1 & 8 & 9 \\
\hline Belize & 0 & 0 & 0 & 0 & 0 & 1 & 1 \\
\hline Bermuda & 0 & 12 & 0 & 2 & 1 & 10 & 25 \\
\hline Bolivia (Plur. State of) & 0 & 0 & 0 & 0 & 0 & 6 & 6 \\
\hline Brazil & 22 & 70 & 23 & 12 & 172 & 198 & 497 \\
\hline Chile & 5 & 2 & 1 & 0 & 10 & 8 & 26 \\
\hline Colombia & 1 & 1 & 0 & 0 & 1 & 5 & 8 \\
\hline Costa Rica & 0 & 1 & 0 & 0 & 2 & 11 & 14 \\
\hline Cuba & 0 & 0 & 0 & 0 & 0 & 2 & 2 \\
\hline Cayman Islands & 2 & 1 & 0 & 4 & 3 & 8 & 18 \\
\hline Dominica & 0 & 0 & 0 & 0 & 1 & 0 & 1 \\
\hline Dominican Republic & 0 & 0 & 1 & 0 & 0 & 1 & 2 \\
\hline Ecuador & 0 & 0 & 0 & 0 & 0 & 9 & 9 \\
\hline Guatemala & 0 & 0 & 0 & 0 & 1 & 3 & 4 \\
\hline French Guiana & 0 & 0 & 0 & 0 & 1 & 2 & 3 \\
\hline Honduras & 0 & 0 & 0 & 0 & 0 & 3 & 3 \\
\hline Mexico & 5 & 3 & 0 & 0 & 14 & 32 & 54 \\
\hline Nicaragua & 0 & 1 & 0 & 0 & 0 & 3 & 4 \\
\hline Panama & 0 & 0 & 0 & 0 & 0 & 3 & 3 \\
\hline Peru & 0 & 0 & 0 & 0 & 0 & 11 & 11 \\
\hline Paraguay & 0 & 0 & 0 & 0 & 0 & 2 & 2 \\
\hline El Salvador & 0 & 1 & 0 & 0 & 0 & 2 & 3 \\
\hline Trinidad and Tobago & 0 & 0 & 0 & 0 & 0 & 2 & 2 \\
\hline Uruguay & 0 & 1 & 0 & 0 & 4 & 0 & 5 \\
\hline Venezuela (Bol. Rep. of) & 0 & 1 & 1 & 0 & 0 & 0 & 2 \\
\hline Total & 36 & 102 & 27 & 18 & 248 & 342 & 773 \\
\hline
\end{tabular}

Source: Prepared by the authors, on the basis of data from Thomson ONE. 


\section{The Latin American Venture Capital Association (LAVCA) database}

The version of the LAVCA database used in this study covers Latin America and Caribbean and spans the period from 2006 to October 2012. The countries in the dataset are: Argentina, Brazil, Chile, Colombia, Costa Rica, the Dominican Republic, El Salvador, Mexico, Panama, Peru, Trinidad and Tobago, and Uruguay. The data are collected by LAVCA from reports by funds, by national private equity and venture capital associations and by funds that report their financial data to institutions such as MIF or IFC. As in the case of Thomson ONE, both the reporting institutions and LAVCA use their own criteria for classifying an investment as VC. Nonetheless, they all base their classification on the nature of the firm, its age and the fact that it is not taken over by another company. For the years after the period covered by this study, the LAVCA database has been used to monitor private equity and VC investments in the region. This paper used it to double check certain magnitudes such as those given in figure 1 and table 1. 